\title{
Emily Dickinson's Volcanic Punctuation
}

Kamilla Denman

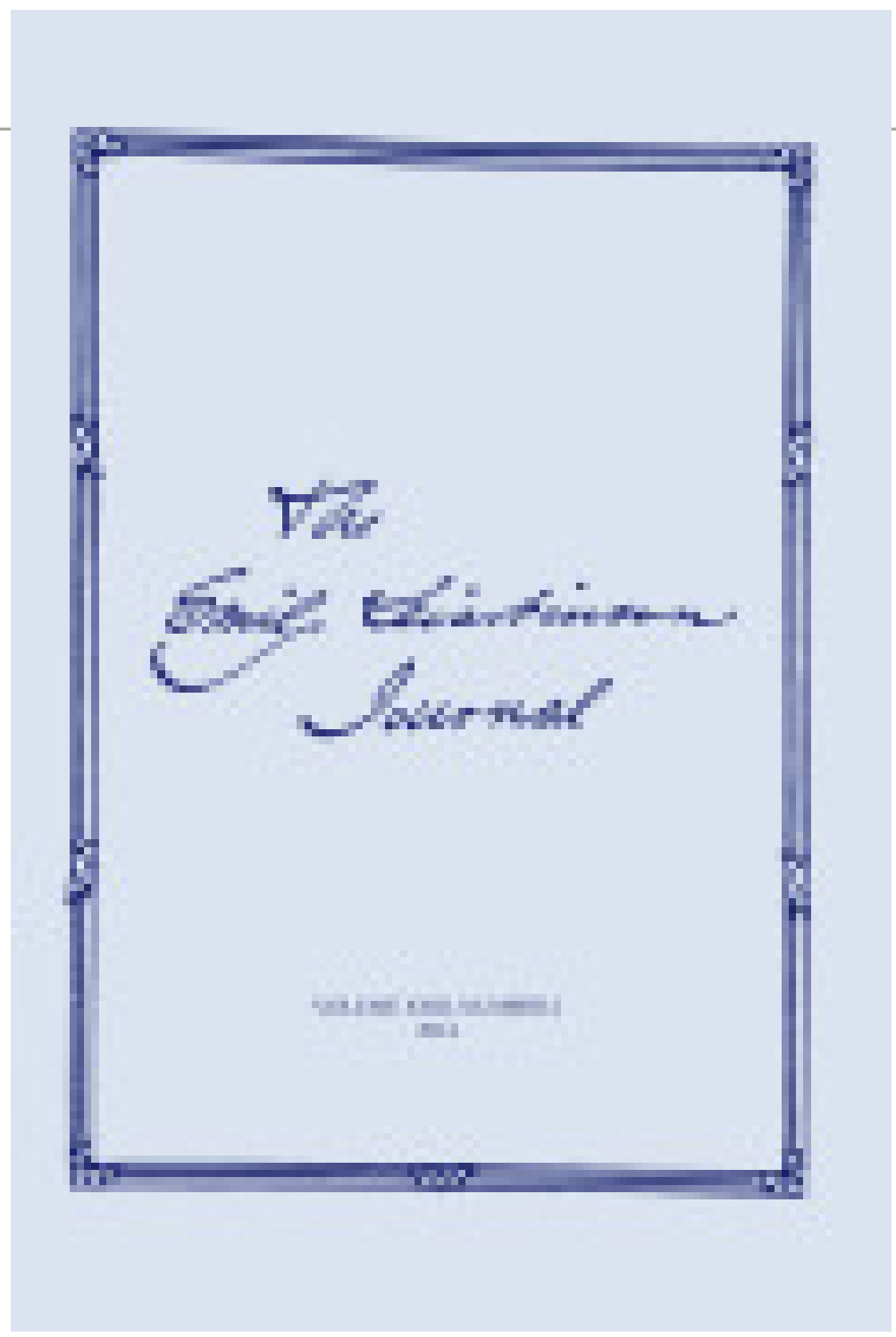

The Emily Dickinson Journal, Volume 2, Number 1, Spring 1993, pp.

22-46 (Article)

Published by The Johns Hopkins University Press

DOI: 10.1353/edj.0.0168 


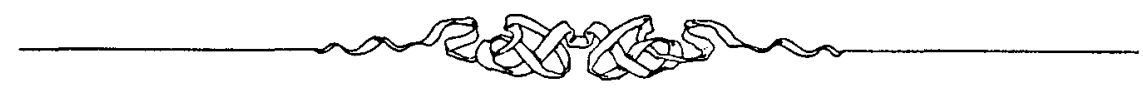

\section{KAMILLA DENMAN \\ Emily Dickinson's Volcanic Punctuation}

What a hazard an Accent is! When I think of the Hearts it has scuttled or sunk, I almost fear to lift my Hand to so much as a punctuation. ${ }^{1}$

6 merson, in his famous lecture on "The American Scholar," declared: of the lips of Etna, lightens the capes of Sicily; and, now out of the throat of Vesuvius, illuminates the towers and vineyards of Naples. It is one light which beams out of a thousand stars. It is one soul which animates all men." ${ }^{2}$ The volcano that animates Dickinson's writing, however, is a far more violent force, an image of devastating linguistic expression erupting out of silence: "Vesuvius dont talk - Etna - dont - one of them - said a syllable — a thousand years ago, and Pompeii heard it, and hid forever - " (L 233). Dickinson's volcano emits not only light but consuming lava:

A still - Volcano - Life -

That flickered in the night -

When it was dark enough to do

Without erasing sight -

A quiet - Earthquake Style -

Too subtle to suspect

By natures this side Naples -

The North cannot detect 
The Solemn - Torrid — Symbol -

The lips that never lie -

Whose hissing Corals part — and shut -

And Cities - ooze away - ${ }^{3}$

In contrast to Emerson's image of benevolent spiritual enlightenment, Dickinson's volcano consumes, burns, and destroys. The volcano is an unpredictable, subversive force, more appalling when it erupts because it has been so long silent. Yet the subtlety of the volcano persists even in the eruption, which is only a hiss, and in the destruction, which is an oozing away. Far from being limited by its constraining rock, the volcano's power of expression is so great that it can swallow up the exterior that seems to confine it. As such, it offers an image of Dickinson writing from within the confines of her society, exploding the language by which her culture seeks to limit and define her. The volcano, though phallic in shape, ejaculating lava, has a feminine component, too: its vaginal and oral lips dispense symbols that scorch the phallus from within and devour the surroundings above and amidst which it has erected itself. The volcano thus evokes the terrifying image of the woman writing from within the male organ(ization) itself. Dickinson's disruption of social structures, like her poetic image of the volcano, is primarily a linguistic one. The volcano destroys cities that are, like conventional language and grammar, constructions of civilization. But just as the fiery lava and ash also resculpt the landscape and enrich the soil, Dickinson's disruption of conventional discourse also reshapes and enriches language.

When Dickinson described the effect of attempting to impose order on her own poetry, she expressed it in volcanic terms: "when I try to organize my little Force explodes — and leaves me bare and charred — " (L 271). The publication history of Dickinson's poems chronicles many subsequent attempts by others to contain her explosive language, and nowhere is this more marked than in the editing of Dickinson's punctuation. Editors usually turn to her punctuation as an area where they can confidently bring some order to her enigmatic poetry. Their assumption is that all writers ought to subscribe to conventional standards of punctuation, and when authors violate these laws, editors must enforce them. ${ }^{4}$ Consequently Dickinson's punctuation is either obscured in earlier editions and made to conform to conventional rules or displayed as a curiosity in later editions and then condemned for deviance. ${ }^{5}$ 
These editorial practices have sparked a lively debate among critics, some of whom seek to rescue Dickinson by imaging her as an eccentric transcendentalist in opposition to the grammatical reprobate whose punctuation editors have both displayed and sought to correct. In the more traditional editorial approach, John Crowe Ransom gallantly suggests that the editor of the next edition "will respect [her] capitalizations, I think, even while he is removing them," a statement that (especially in the context of a male critic discussing a female writer) is not too far from the old adage, "I'll still respect you in the morning." On the other side of the debate, in the musical and elocutionary theories propounded by such critics as Thomas $\mathrm{H}$. Johnson, Brita Lindberg-Seyersted, Edith Perry Stamm, and Susan Howe, Dickinson's punctuation is lifted into the lofty realm of para-language and relegated to a function secondary to semantics and social discourse, a realm where conventional meanings are consequently safe from Dickinson's volcanic disruption.

I will argue that Dickinson's punctuation is neither a transcendent, purely extra-semantic effect nor a careless transgression of grammatical rules but an integral part of her exploration of language, used deliberately to disrupt conventional grammatical patterns and create new relationships between words; to resist stasis in linguistic expression (whether in the conventions of printing or in her own evolving writing); to create musical and rhythmical effects; and to affirm the silent and the nonverbal, the spaces between words that lend resonance and emphasis to poetry. In the punctuation of her poetry, Dickinson creates a haunting, subversive, impelling harmony of language, wordless sound (emotional tonality and musical rhythms), and silence. Like songs set to music, Dickinson's poems are accompanied by a punctuation of varying pauses, tones, and rhythms that extend, modify, and emancipate her words, while pointing to the silent places from which language erupts.

Punctuation has evolved as a system of rules and principles to establish the rel ationship of words to one another in a sentence, otherwise arbitrary, and as a means of bringing tone and emphasis to language. The $O E D$ defines punctuation as "The practice, art, method, or system of inserting points or 'stops' to aid the sense, in writing or printing; division of written or printed matter into sentences, clauses, etc. by means of points or stops. The ordinary sense." 7 Dickinson's definition of a poet, however, is in direct opposition to the idea of ordinary sense: 
This was a Poet - It is That

Distills amazing sense

From ordinary Meanings -

(P 448)

Part of Dickinson's own power to distill amazing sense from ordinary language lies in her innovative use of punctuation.

Editors and critics often lament the posthumous publication of Dickinson's poetry, since it leaves so many unanswered questions, while others have used this fact to create elaborate speculations about Dickinson's intentions. But not all of Dickinson's poems were published posthumously. Dickinson's single comment about punctuation and publication was made following the publication of her poem "The Snake" in the Springfield Republican in 1866. She wrote to her editor-mentor, Thomas Wentworth Higginson, to explain that she had not deceived him in declaring her reluctance to publish: "Lest you meet my Snake and suppose I deceive it was robbed of me - defeated too of the third line by the punctuation. The third and fourth were one - I had told you I did not print - " (L 316). Though the reference to the punctuation is almost an aside, the complaint is clear. In the fascicles, the lines Dickinson mentions were written:

You may have met $\mathrm{Him}_{8}-$ did you not
His notice sudden is -8

The Springfield Republican punctuated them:

You may have met him — did you not? His notice instant is.?

Cristanne Miller claims that if Dickinson objected to a single editorial alteration in one poem, then she would certainly have objected to all other punctuation changes in her work. ${ }^{10}$ But the Springfield Republican made many changes in the punctuation of "The Snake" of which Dickinson did not complain. Capitalization was entirely regularized; stanzas were made uniform; dashes were changed to commas, semi-colons, and periods; punctuation was added where Dickinson used none and vice versa; and two words were 
changed. Traditionally, editors are far more reluctant to change words than to edit punctuation; yet Dickinson let the verbal substitutions pass without comment. Why did she complain only of the one editorial change?

To my knowledge, only one critic has attempted to explain Dickinson's protest. Brita Lindberg-Seyersted suggests that Dickinson's punctuation has a purely rhythmic, rhetorical purpose. Unable to make grammatical sense of the punctuation, she assumes it must have an entirely extra-semantic function. ${ }^{11}$ However, the effect here is more a case of counter-semantics than extra-semantics. The Springfield Republican editor punctuates the lines logically, conversationally, and safely, keeping the "you" fenced off from the snake by a comma, evoking the tone of a casual aside. The sense here is, "You may have met him, didn't you? He gives instant warning of his presence." The sense as Dickinson intended it is something more like, "You may have met him, and if you didn't glimpse him at first, he quickly gives notice of his presence." Dickinson's punctuation pulls the "you" alliteratively ("not/notice") and hissingly ("His notice sudden is") into the same clause with the snake, leaving no space for breath or distance. This effect is verbally echoed in the closing lines: "tighter Breathing/ And Zero at the Bone." Dickinson's punctuation breaks down the conventional, conversational groupings of words as well as the safe distance between speaker and snake. ${ }^{12}$ While Dickinson certainly did use punctuation for musical, rhythmic, and emphatic purposes, perhaps more than any other poet, her pointing system also sought to disrupt and reassemble the relationships between words, volcanic fashion.

At the time of her most disruptive use of punctuation in the early $1860 \mathrm{~s}$, she wrote in exasperation to Samuel Bowles: "The old words are numb - and there a'nt any new ones" (L 252). In the absence of new diction, Dickinson sought to redefine words through dislocating marks of punctuation. In disrupting punctuation, Dickinson reveals the open nature of language that conventional punctuation seeks to regulate and obscure and makes new groupings and relationships between words apart from linguistic conventions. Thus her punctuation has a semantic as well as an extra-semantic function.

Charles F. Meyer says that the essential function of punctuation can be summed up under the rubrics of separation and enclosure. ${ }^{13}$ Words that belong together are enclosed by punctuation and separated from other words. ${ }^{14}$ Without changing or moving a single word in a sentence, William Klein, in 
Why We Punctuate (1916), shows how the insertion of two tiny marks of punctuation can make a sentence mean the opposite of its original sense:

The prisoner said the witness was a convicted thief.

The prisoner, said the witness, was a convicted thief. ${ }^{15}$

In the first, the witness is implicated by the prisoner; in the second, the implication is reversed. This is no fine, scholarly distinction.

While Dickinson did not go so far as to make words mean their logical opposite, she did disrupt conventional arrangements to create emotional and psychological effects, as in the lines of "The Snake" above. A more extended example of this process appears in poem 341 :

After great pain, a formal feeling comes -

The Nerves sit ceremonious, like Tombs -

The stiff Heart questions was it $\mathrm{He}$, that bore,

And Yesterday, or Centuries before?

The Feet, mechanical, go round -

Of Ground, or Air, or Ought -

A Wooden way

Regardless grown,

A Quartz contentment, like a stone -

This is the Hour of Lead -

Remembered, if outlived,

As Freezing persons, recollect the Snow -

First - Chill — then Stupor — then the letting go -

The poem begins with words conventionally grouped (though the punctuation marks Dickinson used were not conventional), but by the third line, the grammar of the poem begins to disintegrate with the introduction of an additional comma, leaving only the iambic pentameter as a stabilizing if relentless rhythmic force throughout the first stanza. ${ }^{16}$ The first line describes the psychological state philosophically, the second describes it imagistically, and the two make an impressive epigram. But Dickinson is not content to end the poem here: she must explore the state from a more intimate and vulnerable standpoint. She is not content to recollect emotion in tranquillity, nor to 
describe it in eloquent, complete sentences. The introduction of the subject, "He," causes the clear ideas and images of the first two lines to crumble into disconnected images and fragmented phrases. The comma that follows the word, "He," is the first signal of the breakdown in the syntax, separating predicate nominative from its relative pronoun and verb, and person from action. The disruptive comma also creates a temporal dislocation that permeates the poem: the present thought is not completed (the object of "bore" is lacking), as the speaker unsuccessfully seeks to locate the incomplete action in past time. The present experience described in the second stanza is a mechanical, cyclical treadmill, while the past of the first stanza stretches out vaguely and endlessly. In the final stanza, past and present are confused in the line, "Freezing persons, recollect the Snow." The present participle evokes a present condition, but the snow that is causing the freezing is disconcertingly thrown into the chasm of the past by the verb, "recollect." The experience of freezing is so intensely present that even the snow that causes it, like the "He" who bore the pain, seems to belong in the past.

Temporal dislocation in the content of the poem is integrally related to its syntactic and metrical form. Generally, the order of words in temporal sequence establishes linguistic relationships from which meanings emerge. In this poem, the temporal disruption of the speaker's psyche extends to the syntax and meter, with incomplete sentences and sudden shifts from pentameter to tetrameter to trimeter to dimeter and back. Other phrases in the poem initially seem to form complete sentences but then unravel in subsequent lines that confuse the original meaning, as in the last stanza. There are no periods to mark off any thought as complete, nor even to mark the poem as a complete thought: the final sentence is completely fragmented by dashes. Alan Helms, in his incisive reading of the punctuation in this poem, says that the dashes in the last line approximate the experience of freezing by slowing down the tempo. ${ }^{17}$ The final verb, "letting go," is followed by a dash that hangs the poem and the experience described in the poem over a visual and aural precipice of frozen silence. Were the sentences to be made complete and the poem conventionally punctuated, the essence of the experience it describes would be lost. Clearly, much of Dickinson's power in evoking psychological states lies in her disregard for conventional rules of grammar and punctuation, as well as conventional rules of poetic meter, line, and rhyme. 
Such disregard inevitably evoked editorial correction and critical comment. Dickinson's belatedly revealed punctuation in Johnson's 1955 variorium edition caused a critical furor in which R. W. Franklin has had the last word. He roundly attacks all theories giving significance to Dickinson's punctuation in musical, mythopoetic, elocutionary, or any other terms: " $\mathrm{Fa}$ miliarity with the manuscripts should show that the capitals and dashes were merely a habit of handwriting and that Emily Dickinson used them inconsistently, without system . . . without special significance." To support his argument, he shows how Dickinson used the same style of capitalization and punctuation in letters, in copying excerpts from books, and in handwritten recipes. He then ridicules theories of Dickinson's punctuation by applying them to a recipe for Cocoa Nut Cake that Dickinson penned in 1881:

If we follow John Crowe Ransom's theory, the capitals are Emily's "way of conferring dignity" upon the ingredients of Mrs. Carmichael's cake, or are her "mythopoetic device" for pushing Butter, Flour, 6 Eggs, and a Cocoa Nut (grated) into "the fertile domain of myth." At the same time, according to Charles R. Anderson, we are asked to use the punctuation here as "a new system of musical notation for reading" the recipe. Or, applying Miss Stamm's theory, Emily Dickinson has not only got the recipe, but has indicated how one is to declaim it. ${ }^{18}$

But Dickinson's single comment about punctuation can provide a baseline theory that will satisfy even the rigorous critical demands of Mrs. Carmichael's recipe. In her comment on the publication of "The Snake," Dickinson says that words not separated by punctuation are "one." Dickinson used punctuation to create units of words, words that were one, enclosed within marks of punctuation and separated from other words by these marks. These units were not immutable, as is clear from the differing punctuation in various extant versions of the same poems. Dickinson's manuscripts show that she grouped and regrouped her units of speech, never allowing words to remain static or in static relationship to other words. The reasons that words belong together are multiple. Words can be unconventionally joined to disrupt conventional patterns and meaning or separated against grammatical convention to explore the inherent dissociation and ambiguous nature of language. Word groupings can communicate heightened tone and emotional force, as in the highly 
charged poems of 1861 , written with more disrupting dashes than in any other year. Rhythmic, tonal, imagistic, or aural demands of the poetry can require unconventional groupings. Or words can simply be the ingredients of a cocoa nut cake, separated in order to be gathered, broken, beaten, combined, and baked in order to create a new whole. The recipe is not such a ridiculous analogy after all.

In this constant process of separation and recombination, Dickinson not only subverted conventional language through punctuation, she continually submitted her own language to the same disruptive process. She was her own rigorous, if unconventional editor. Critics have been reluctant to see changes in Dickinson's poetry over time, generally claiming that Dickinson's style is static. As Timothy Morris says: "It has become a given of Dickinson criticism that the poet's style never changed."19 For example, Sharon Cameron writes: "If we could observe changes in the style of the poems, it might be easier to arrive at textual decisions. But, in fact, as most critics agree, there is no development in the canon of poems. The experiences recorded by these poems are insular ones, subject to endless repetition." ${ }^{20}$ Morris, however, goes on to challenge this idea in relation to Dickinson's use of enjambment and rhyme. A study of the patterns of punctuation in Dickinson's poetry over time also reveals a practice that was far from static. ${ }^{21}$ Dickinson's exploration of language took her from conventional punctuation in the earliest poems through a prolific period where punctuation pulled apart every normal relationship of the parts of speech, to a time of grim redefinition punctuated by weighty periods, on to a final stage where language and punctuation are minimal but intensely powerful. ${ }^{22}$

While the themes of Dickinson's poems remained constant throughout her life - love, death, nature, and religion - the variations in punctuation over time create a marked difference in the tone of the poems. Punctuation not only guides meaning, it adds expression and affect to language. William Livingston Klein illustrates:

John has gone home. John has gone home? John has gone home! $!^{23}$ 
Here, variant punctuation of identical words evokes three entirely different speakers, and even three different interpretations of the sentence. The first statement simply informs us that John has gone home; the second indicates doubt regarding the statement; and the third expresses strong emotion regarding John's departure - but whether the emotion is one of surprise, disapproval, horror, triumph, fear, joy, or grief cannot be determined apart from a larger context.

While Dickinson's earliest poetry was conventionally punctuated, by 1858 she is consistently using highly individualized punctuation to create an intensity of tone in her poems. The overuse of the exclamation mark is the most pronounced punctuation feature of this period and occurs in letters as well as in poems. Describing a scene to Dr. and Mrs. J. G. Holland, Dickinson writes: "My window overlooks the wharf! One yacht, and a man-of-war; two brigs and a schooner!" (L 195). Here, she communicates her enthusiasm for her surroundings through punctuation alone. Poem 92 provides a brief example of the same overuse:

My friend must be a Bird -
Because it flies!
Mortal, my friend must be,
Because it dies!
Barbs has it, like a Bee!
Ah, curious friend!
Thou puzzlest me!

The general mood in 1858-1859 is one of intensity, whether arising from joy, pain, playful satire, or exultant discovery, and Dickinson relies heavily on the exclamation mark to create this mood. The exclamation mark is a vertical, phallic figure, connected with the certainty of "Eureka!" and with erections, steeples, and religious faith. The verb, "exclaim," from which the mark derives its name, has various meanings. According to the $O E D$, it signifies "the act of exclaiming or crying our; the loud articulate expression of pain, anger, surprise, etc.; clamour, vociferation; an emphatic or vehement speech or sentence; the action of loudly complaining or protesting." 24 Dickinson's early poetry is certainly filled with exclamations of pain and protest, as well as moments of surprise and exultation. There is also a sense of dramatic intention and control 
in these early poems: so many final exclamatory lines come like the unveiling of a surprise that the author has known from the start.

By contrast, the poems of 1860-1863 are less controlled and directed, as the punctuation indicates. By 1862, the exclamation mark is increasingly rare. In this period, Dickinson becomes anarchic in her use of the dash, both in terms of its replacement of almost every other mark of punctuation and in its placement between almost every one of the parts of speech, as the following poems illustrate:

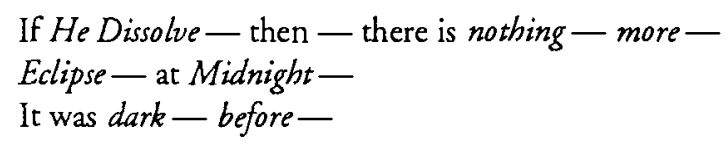

Read - Sweet - how others - strove -

Till we - are stouter -

What they - renounced -

Till we - are less afraid -

(P 260, ca, 1861)

This anarchic practice occurs in letters as well as poems. A letter written to Samuel Bowles about February 1861 reads: "To count you as ourselves except sometimes more tenderly — as now - when you are ill — and we the haler of the two - and so I bring the Bond - we sign so many times for you to read, when Chaos comes - or Treason - or Decay — still witnessing for Morning" (L 229).

Unlike the exclamation mark, the dash that dominates the prolific period is a horizontal stroke, on the level of this world. It both reaches out and holds at bay. Its origins in ellipsis connect it semantically to planets and cycles (rather than linear time and sequential grammatical progression), as well as to silence and the unexpressed. But to dash is also "to strike with violence so as to break into fragments; to drive impetuously forth or out, cause to rush together; to affect or qualify with an element of a different strain thrown into it; to destroy, ruin, confound, bring to nothing, frustrate, spoil; to put down on paper, throw off, or sketch, with hasty and unpremeditated vigour; to draw a pen vigorously 
through writing so as to erase it; [is] used as a euphemism for 'damn,' or as a kind of verbal imprecation; [or is] one of the two signals (the other being the dot) which in various combinations make up the letters of the Morse alphabet." ${ }^{25}$ Dickinson uses the dash to fragment language and to cause unrelated words to rush together; she qualifies conventional language with her own different strains; and she confounds editorial attempts to reduce her "dashed off" jottings to a "final" version. Not only does she draw lines through her own drafts but also through the linguistic conventions of her society, and her challenges to God are euphemistic imprecations against conventional religion. Even the allusion to the Morse alphabet is not entirely irrelevant: through her unconventional use of punctuation, particularly the dash, Dickinson creates a poetry whose interpretation becomes a process of decoding the way each fragment signals meaning.

Dickinson's transition from a dominant use of the exclamation mark to a preference for the dash accompanies her shift from ejaculatory poems, which seem outcries aimed with considerable dramatic effect at God or others, to poems where the energies exist more in the relationships between words and between the poet and her words. In this intensely prolific period, Dickinson's excessive use of dashes has been interpreted variously as the result of great stress and intense emotion, ${ }^{26}$ as the indication of a mental breakdown, ${ }^{27}$ and as a mere idiosyncratic, female habit. ${ }^{28}$ Though these speculations are all subject to debate, it is clear that in the early 1860 s Dickinson conducted her most intense exploration of language and used punctuation to disrupt conventional linguistic relations, whether in an attempt to express inexpressible psychological states or purely to vivify language.

Whatever Dickinson's motivation may have been, readers have found her excessive use of dashes in the poems of this period somewhat jarring. Critics who complain of Dickinson's punctuation and those who defend it alike remark on its aural and rhythmic effects. Alan Helms likens the dynamic interplay of music and silence to poetry and punctuation. ${ }^{29}$ Given the rhythmic function of punctuation in poetry, it is not surprising that so many critics have posited a musical theory of Dickinson's punctuation. Whereas Dickinson certainly characterizes her writing in volcanic terms, more often she often equates her poetry with music, identifying herself as a singer and a robin ("I shall keep singing! / . . I — with my Redbreast — / And my Rhymes - " 
P 250). Although the two images seem quite disparate, in poem 861 they connect:

Split the Lark - and you'll find the Music -

Bulb after Bulb, in Silver rolled -

Scantily dealt to the Summer Morning

Saved for your Ear when Lutes be old.

Loose the Flood - you shall find it patent -

Gush after Gush, reserved for you -

Scarlet Experiment! Sceptic Thomas!

Now, do you doubt that your Bird was true?

Like volcanic lava or the waters of a flood, the music of the bird resides within, and its expression is an overflowing of inner essence. But whereas volcanic fire supplants existing structures only on rare occasions, and then on a grand scale, the bird's "silver Principle / Supplant[s] all the rest" on a smaller, daily scale (P 1084).

It is important to note that Dickinson is not a musical poet in the purely lyrical sense of the word: she saw herself as a translator of music into language:

Better - than Music! For I - who heard it I was used - to the Birds - before -

This - was different - 'Twas Translation -

Of all tunes I knew - and more -

'Twas'nt contained - like other stanza -

No one could play it - the second time -

But the Composer - perfect Mozart -

Perish with him — that Keyless Rhyme!

But - I was telling a Tune - I heard -

Not such a strain - the Church - baptizes -

When the last Saint - goes up the Aisles -

Not such a stanza splits the silence -

When the Redemption strikes her Bells -

Let me not spill — it's smallest cadence -

Humming - for promise - when alone - 
Humming - until my faint Rehearsal -

Drop into tune - around the Throne -

(P 503)

In songs, music expands the space and pitch in which words are uttered; it lends affect and emphasis to language; it can undercut or underline the words it accompanies; it can blend words or dislocate them from their context. Clearly, it functions in much the same way as punctuation in Dickinson's poetry. To look at Dickinson's punctuation purely as a disruption of language, then, is to miss this musical dimension, where the semantic and rhythmic disruptions are smoothed through an implied melody.

Given the limited form of the hymn or ballad stanza, punctuation provides an important temporal variation within the relentless rhythms of the meter, but it is often a variation that readers find disruptive or jarring. Critics are fond of pointing out how Dickinson went beyond the hymnody and ballads of the period in her use of common meter, but a look at the music of nineteenth-century hymns is elucidating with regard to her punctuation. Her meter, used in the ballads, hymns, and nursery rhymes of the period, is essentially a musical one. Dickinson's meter is all too often connected to hymns and then divorced from the music that would have accompanied those hymns. Any nineteenth-century ballad meter hymn read as a poem sounds monotonous, mechanical, and trite. But when it is sung, the music temporally expands the words, often allotting several notes to a single word; and it adds texture through variations in tone and pitch. The four-part harmonies deepen this texture and create multiple ways of singing and experiencing the words through music.

When sung to any of the tunes that accompanied the hymns of Isaac Watts and John Newton (such as Handel's music for "Joy to the World" or Haydn's for "Glorious Things of Thee Are Spoken"), Dickinson's poems take on a completely different texture, so that the punctuation works with, not against, the meter. A similar effect is produced by the application of nineteenth-century ballad tunes to Dickinson's poems. ${ }^{30}$ All too often, Dickinson scholars read the poems in silence or aloud at the speed of nursery rhymes, rather than in the musical context that liberates common meter from the mechanical and the banal. Read quickly, the poems seem metrically disrupted 
by the punctuation. But when the poems are read at the tempo at which metrically similar hymns would have been sung, the rhythmic disruption vanishes. While there is no evidence that Dickinson had contemporary music in mind when she wrote her poems, her repeated references to herself as a singer and the hymns in which her culture was steeped mean that this possibility cannot be excluded. Since the publication of her poems at the end of the nineteenth century, composers have been fully aware of the musical potential of her poetry, as evinced by the frequency with which her poems have been set to music. ${ }^{31}$

In musical terms, one could say that after 1863 , Dickinson's poetry moves from allegro to andante, for there is a distinct shift in the diction, tone, and punctuation of these later poems. Images of spring, summer, birds, and flowers are largely replaced by wintry images of wind, thunder, lightning, clouds, and frost. Instead of views toward a limitless future, there is a distinct sense of loss and bitter nostalgia (see, for example, poems 744,755 , and 753 ). In this period, Dickinson's assault on language takes the form of redefining words rather than the disruption of syntax through punctuation. Many poems fall under the rubric of definitional poems, beginning, for example, with the words "Love is," "Time is," "Power is," or "Risk is." 32 The more sober mood is marked by sparser and heavier punctuation: periods begin to settle at the end of poems, while dashes are sparingly used. Though Dickinson still grapples with themes of love, death, and separation, she is now more concerned in this enterprise with generalities and universals. The poetry of the "I" has become the poetry of the "we." 33

From 1870 on, a number of poems have no punctuation at all. But the absence as well as the presence of punctuation is significant. In this period, Dickinson seems to be thinking increasingly in ballad meter, creating word groupings based on the metrics of trimeter and tetrameter. When a phrase is not contained by the meter, she uses punctuation to indicate grouping, but almost as often she adds a line break instead of punctuation to separate words. Clearly, punctuation is not an indispensable part of composition at this stage, though it is still an ingredient. But even in this partial abandon of punctuation, Dickinson continues to be unconventional, resisting as always the containment and closure inherent in rules of punctuation. 
With the diminishing use of punctuation there is also a decrease in the number of words in poems and letters. Dickinson herself explains: "I hesitate which word to take, as I can take but few and each must be the chiefest, but recall that Earth's most graphic transaction is placed within a syllable, nay, even a gaze - " (L 873, 1880). In her writing, one might say Dickinson moves increasingly towards silence, a quality she affirms throughout her poetry and letters. In part, this move indicates a rejection of her highly verbal society. Dickinson explains her social withdrawal in terms of avoiding discourse: "Of 'shunning Men and Women' - they talk of Hallowed things, aloud — and embarrass my Dog - He and I dont object to them, if they'll exist their side" (L 271). Poem 1159 places her value of silence in an even more anti-cultural context:

\author{
Great Streets of silence led away \\ To Neighborhoods of Pause - \\ Here was no Notice - no Dissent \\ No Universe - no Laws - \\ By Clocks, 'twas Morning, and for Night \\ The Bells at Distance called - \\ But Epoch had no basis here \\ For Period exhaled.
}

(ca. 1870)

In Dickinson's imagined locale, which may be her vision of eternity in contrast to the Christian one, language is absent, but more significant are its concomitant absences: attention, disagreement, the universe with its universal laws, linear time, and "Period." In the last, Dickinson plays on the temporal and punctuational definitions of the word by refusing to give it an article or any other definition, glibly placing a period after it in one extant version of the poem and letting it exhale in a dash in the other. Though the poem primarily refers to absent items, the things that are present in the poem are revealing. Dickinson's silence is not a total one, but one filled with rhythm and wordless music in the ticking clocks and tolling bells. Linear time is replaced by cyclical time in the clocks, which are visual symbols of endlessly repeating units of time. The tolling of bells, which traditionally marks significant points in the 
life cycle and the liturgical cycle, contributes to the erosion of linear time and the affirmation of the recurring. In the exhaling period, Dickinson points to a silence and a pause not only beyond language but beyond punctuation.

But despite her visionary foray beyond society, language, and punctuation, the poem that describes the "Neighborhoods of Pause" is written in words, and it is punctuated. Punctuation not only groups words, indicates tone, and marks rhythms, it creates places of silence in the pauses between words, a function that Dickinson utilized fully. In her earlier poems, dashes create disruptive and lingering pauses beyond anything required by conventional rules of punctuation. The following poem illustrates this practice:

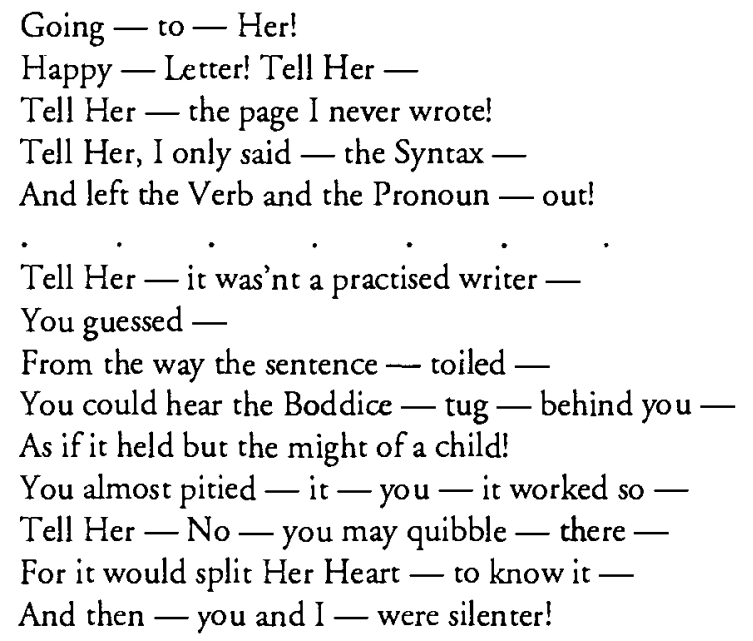

(P 494, ca. 1862)

The punctuation and syntax create a halting but emotionally charged tone and mark the silent places where the speaker either cannot or dares not write. The image used to express this inability to communicate is, appropriately, grammatical: the writer announces that the verb and the pronoun, the active and personally indicative parts of the "sentence" that stands for her inner thought, have been omitted. But the breakdown of grammar is not merely an image for the unutterable: it occurs in the form of the poem as well, as in the lines, "You almost pitied — it — you — it worked so - / Tell Her — No - you may quibble - there - ." The stretching stitches of the tugging bodice and the 
erratic beat of the speaker's bursting heart are visually and aurally represented by the stitch-like, pulsing dashes of the poem. Like the heartbeat of a tremulous person, they create an irregular rhythm that also disrupts the smooth flow of grammar in the poem.

By contrast, Dickinson's later poems contain little or no punctuation; yet they are shorter and fewer, indicating that if the poet continues to ponder the silent and the wordless, she does so by being more sparing of words:

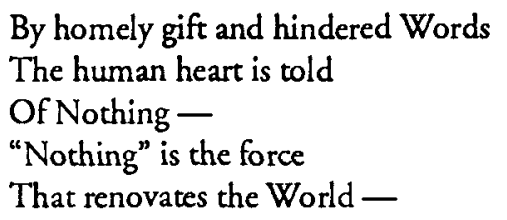

(P 1563, 1883)

Here, the hindered, halting words of the earlier poem are condensed into a minimally punctuated poem of far fewer words. The unutterable behind the hindered words is no longer an unexpressed thought that the speaker fears to communicate; it is rather a formless, renovating force that exists not so much behind language as in spite of language. Again, the form of the poem reinforces its content: it cuts itself down to the fragment, "Of Nothing," from which it then reasserts itself to complete the ballad rhythm set up at the beginning, adding an off-rhyme for a further sense of resolution. But as in many of her poems, the dash at the end leaves the poem open, pointing towards the silence, the nothing that renews and renovates not only the world, but the words that create and express it.

Silence provides not only the time and space in which words can be uttered and heard but is for Dickinson a generating source of language: "The Lassitudes of Contemplation / Beget a force" (P 1592). Silence is not a void but rather a fullness from which the most powerful language emerges:

Declaiming Waters none may dread But Waters that are still

Are so for that most fatal cause

In Nature - they are full - 
The silence preceding a flood, like poetic silence, is pregnant with lethal power.

For all her interest in words and their arrangements, Dickinson was profoundly drawn to silence and the nonverbal. Dickinson was convinced that the greatest things impress their presence without words:

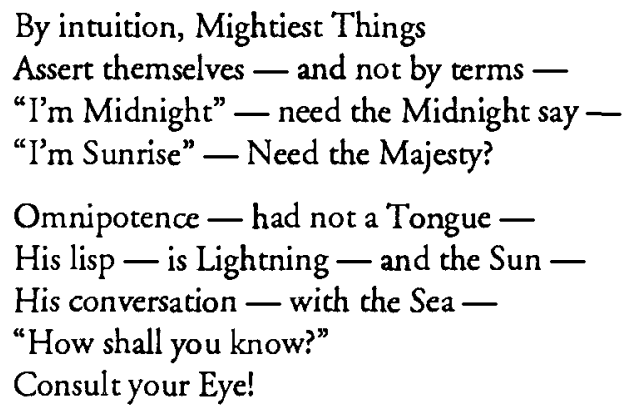

Her poems often celebrate mute, natural beauty at the expense of her own language. With a flower, she sent the following poem:
All the letters I can write
Are not fair as this -
Syllables of Velvet -
Sentences of Plush

The Dickinson poem is thus paradoxically anti-poctry: "True Poems flee" like a summer sky (P 1472). Yet the paradox circles and reverberates endlessly, for this observation is expressed in a poem. Dickinson turns the silent and the nonverbal into language: "There's a noiseless noise in the Orchard - that I let persons hear" (L 271). She thus becomes a translator of silence as well as of music into language.

Nowhere is this more apparent than in her latest poetry. In the $1880 \mathrm{~s}$, there is a quiet exultation in the inner life, in transcendence, in mystery, and in what cannot be expressed through language, despite the many elegiac poems of the period. Dickinson's last poems represent the brief and compressed poetry that she had spent her life preparing to write and deserve much more 
critical attention than they have received. Towards the end of her life, she described the process by which one moves from propped up dependence to mature self-sufficiency:

The Props assist the House

Until the House is built

And then the Props withdraw

And adequate, erect,

The House support itself

And cease to recollect

The Augur and the Carpenter -

Just such a retrospect

Hath the perfected Life -

A past of Plank and Nail

And slowness - then the Scaffolds drop

Affirming it a Soul.

The same claim might be made for the perfected poem. Among the props that Dickinson used to build her poems are marks of anguished and exultant exclamation, defiant and playful questioning, hesitant and tantalizing pauses, and disruptive, musical, elliptic dashes. At the end of her life, these marks increasingly fall away, leaving words and lines of poetry largely undirected and uncontrolled by the restrictions of punctuation.

Like the robin to which she so often compared herself, Dickinson was "a Gabriel / In humble circumstances," a member of "Transport's Working Classes," writing with an "oblique integrity," "As covert[ly] as a Fugitive, I Cajoling [the] Consternation" of readers, editors, and critics "By Ditries to the Enemy / And Sylvan Punctuation" (P 1483). Dickinson uses the syntactic, affective, rhythmic, and tonal functions of punctuation with great innovation and effect, disrupting the reader's syntactic expectations and charging her poetry with intensity. Concomitantly she soothes these disruptions and eruptions with musical rhythms and long pauses which point to silence.

"Sylvan Punctuation" evokes the symbolic and mythical associations of the woods, which Marie Louise von Franz has described in her Interpretation of Fairy Tales: "A wood is a region where visibility is limited, where one loses 
one's way, where wild animals and unexpected dangers may be present, and therefore, like the sea, it is a symbol of the unconscious. ... Aside from this, wood is vegetable life, an organic form that draws life directly from the earth and transforms the soil. Through plants inorganic matter becomes living." 35 The robin's punctuation, the devices used to shape and guide its music, has been learned in the woods, in a mythical and unconscious place apart from society. Dickinson's "Sylvan Punctuation," learned from the robin who is her "Criterion for Tune - / Because I grow - where Robins do - " (P 285) in a self-imposed exile from society, is consequently mystifying, circular, elusive, full of unexpected turns that cause readers to lose their way. It lies outside the orderly structures of her society and ours, is closely connected to the unconscious, nonverbal aspects of the human psyche and of music, and is one of the ways in which she makes the inorganic matter of language into living poetry. Dickinson's woods are even more pregnant and threatening than the woods of myths and fairy tales, for they grow on a volcano:

On my volcano grows the Grass

A meditative spot -

An acre for a Bird to choose

Would be the General thought -

How red the Fire rocks below

How insecure the sod

Did I disclose

Would populate with awe my solitude

\section{Notes}

1. Penciled draft found among Dickinson's papers at her death. Cited in Emily Dickinson, The Letters of Emily Dickinson, eds. Thomas Johnson and Theodora Ward, 3 vols. (Cambridge: Belknap P of the Harvard UP, 1958) 3: 1011. All further references to this source will be cited parenthetically as $\mathrm{L}$, followed by the number of the letter.

2. Ralph Waldo Emerson, "The American Scholar," Selections from Ralph Waldo Emerson: An Organic Anthology, ed. Stephen E. Whicher (Boston: Houghton Mifflin Co., 1960) 67. 
3. Emily Dickinson, The Poems of Emily Dickinson, ed. Thomas H. Johnson, 3 vols. (Cambridge, MA: Belknap P of Harvard UP, 1955) 2: 601. Further references to Dickinson's poems from this source are referenced parenthetically as $P$, followed by the number Johnson assigned to the poem.

4. In Dickinson's day, the punctuation of poetry was not considered separately from that of prose. Joseph A. Turner, a contemporary of Dickinson, remarks in his Handbook of Punctuation that "The laws for the punctuation of poetry are the same as those for the punctuation of prose" (Philadelphia: J. B. Lippincott \& Co., 1876, 66). It must be stressed that ideas about punctuation were by no means uniform in Dickinson's time. In the eighteenth and nineteenth centuries, there was a lively debate about pointing theory. The elocutionary school held that punctuation had a primarily rhetorical function: to indicate the length of pauses and rises and falls in the voice when declaiming a written piece. But as the medium of print became more widespread, the syntactic school gained increasing support, claiming that the primary function of punctuation was to reveal the grammatical structure of each sentence. In the absence of a voice to clarify ambiguities about the relations of words to one another, the eye must take the place of the ear in receiving and interpreting meaning. Park Honan tells us that by mid-century, the syntactical view had prevailed over the elocutionary (Park Honan, "Eighteenth and Nineteenth Century English Punctuation Theory," English Studies 46.2 (1960): 92-102.

5. Mabel Loomis Todd, Dickinson's first editor, remarked: "I am not surprised at the success of the poems, for there is nothing like them in English. Their haunting, compelling effect upon me while I was putting the seven hundred into shape was beyond anything I can express." For Todd, putting these compelling poems "into shape" required smoothing rhymes, adding titles, omitting stanzas, altering words, and regularizing punctuation (Millicent Todd Bingham, Ancestors'Brocades: The Literary Debut of Em ily Dickinson, New York: Harper, 1945, 83). Thomas H. Johnson, after all his efforts to restore the original punctuation in 1955, wrote in the preface to his edition: "Her use of the dash is especially capricious. ... Within lines she uses dashes with no grammatical function whatsoever ... Quite properly such 'punctuation' can be omitted in later editions" (Preface to The Poems of Emily Dickinson, 3 vols., Cambridge, MA: Belknap P of Harvard UP, 1955, 1: lxiii). R W. Franklin, who took great pains to order her packets as they had been at her death and produce a facsimile edition of her poems, argues the need for 'a readers' text whose capitalization and punctuation conform to modern usage," edited by a god-like "editor, critic, and philosopher in one" who has struggled with "editorial and critical principles even to the limits of ontology and epistemology" (The Editing of Emily Dickinson: A Reconsideration, Madison: U Wisconsin P, 1967, 128, 143).

6. Cited in Charles R Anderson, Emily Dickinson's Poetry: Stairway of Surprise (New York: Holt, Rinehart, and Winston), 344.

7. J. A. Simpson, and E.S.C. Weiner, eds., Oxford English Dictionary, 2nd ed., 20 vols. (Oxford: Clarendon P, 1989) 10: 841.

8. P 986; fascicle as it appears in R. W. Franklin, The Manuscript Books of Emily Dickinson (Cambridge, MA: Belknap P of Harvard UP, 1981). 
9. As printed in the Springfield Republican, February 14, 1866.

10. Cristanne Miller, Emily Dickinson: A Poet's Grammar (Cambridge, MA: Harvard UP, 1987), 50.

11. Brita Lindberg-Seyersted, The Voice of the Poet: Aspects of Style in the Poetry of Emily Dickinson, Acta Universitas Upsal iensis, Studia Anglistica Upsaliensia 6 (Upsala: Almqvist \& Wiksells Boktryckeri, 1968), 195-196.

12. The version Dickinson sent to Susan in 1872 shows that the conventions of print had no impact on her choice of punctuation, except to reinforce her original intentions. To avoid the intrusive editorial placement of the question mark, she puts her own at a point which would render it impossible under conventional standards to add the Republican's question mark:

You may have met him? Did you not

His notice instant is -

Dickinson's re-writing of this poem after its publication offers crucial evidence that her reluctance to publish was based, at least in part, on an aversion to the conventions of print. When Todd and Higginson (the latter the recipient of the protesting letter) published "The Snake" in 1891, they followed the example of the Republican, ignoring Dickinson's defense of her punctuation. Other editors followed suit, favoring grammatical sense and conventional practice over Dickinson's "intention." Bolts of Melody, edited by Millicent Todd Bingham in 1945, was a notable exception.

13. Dickinson herself lived a life of self-imposed separation and enclosure in which she explored these new relationships between words.

14. Charles F. Meyer, A Linguistic Study of American Punctuation (New York: Peter Lang, 1987), 4.

15. William Livingston Klein, Why We Punctuate; or Reason versus Rule in the Use of Marks (Minneapolis: Lancet, 1916), 8.

16. Lineation and meter also contribute to the ensuing fragmentation and disruption: the second stanza expands to five lines, and the poem oscillates between iambic pentameter, ballad meter, and tetrameter.

17. Alan Helms, "The Sense of Punctuation," The Yale Review 69.2 (1980): 188-189.

18. Franklin, Editing, 120-121.

19. Timothy Morris, "The Development of Dickinson's Style," American Literature 60.1 (1988): $26-41$.

20. Sharon Cameron, Lyric Time: Dickinson and the Limits of Genre (Baltimore: Johns Hopkins UP, 1979), 14.

21. Issues of dating are crucial for an argument such as this one. The objection may be raised that the date of packet copies does not necessarily coincide with the date of composition. However, from the point of view of punctuation, this does not matter. Dickinson's punctuation evolved as an integral part of her writing, and poems composed earlier and 
copied later are copied using the punctuation characteristic at the time of copying, not at the time of composition. Poem 174, for example, has extant manuscripts in the handwriting of 1860 and of 1862 . In the former, there are many more exclamation marks. In the latter, dashes predominate, replacing commas and all exclamation marks but one, and appearing as well in places where there was no punctuation in the earlier version.

22. In light of attempts to dismiss Dickinson's unusual use of punctuation as idiosyncratic or a mere habit, one cannot stress sufficiently how completely conventional she was in her earliest poetic punctuation. Poem 1, written in 1850 , contains only two of the dashes for which she was to become (in) famous; it has five semi-colons and one colon (as many as she used in the entire future course of her poetic career after 1853), and fifty-nine commas.

23. Klein, 2.

24. $O E D, 5: 507-508$.

25. $O E D, 4: 257-259$.

26. Theodora Ward, "Poetry and Punctuation," Letters to the Editor, Saturday Review (1963) 46: 25 .

27. John Cody, After Great Pain: The Inner Life of Emily Dickinson (Cambridge, MA: Belknap P of Harvard UP, 1971), 291-355. Although Cody does not refer explicitly to the punctuation, he regards the disintegration of Dickinson's language as indicative of her psychosis.

28. Franklin, 124.

29. Helms, 177.

30. Since this is an aural argument, the only proof I can suggest is for the reader to test the theory vocally.

31. Aaron Copland (Eight Poems of Emily Dickinson for Voice and Chamber, 1981), John Adams (Harmonium for Chorus and Orchestra, 1988), George Walker (Emily Dickinson Songs, 1986), and Ernst Bacon (O Friend, 1946) are examples of those who have set Dickinson's poetry to various forms of music.

32. See, for example, poems 1238, 1239, 1241, 1251, 1255, 1292, 1306, 1316, 1329, 1331, $1340,1347,1350,1354,1356,1372,1376,1385,1392,1412,1416,1417,1445,1455$, $1474,1475,1482,1491,1506,1508,1530,1547,1563,1575$. Though Johnson chose to date poems by concrete historical evidence and by the handwriting, several poems not dated by Johnson in the absence of manuscripts or historical data could reasonably be assigned to this period by the diction, tone, and style (for example, poems 1652, 1657 , $1654,1660,1716,1763)$.

33. See, for example, poems $1157,1165,1172,1214,1235,1240,1242,1375,1452,1496$, $1505,1507,1589$.

34. Another fair copy reads "mighty cause": the two adjectives combined evoke the deadly power of the volcano, Dickinson's "explosive force." 
35. Marie Louise von Franz, Interpretation of Fairy Tales (Dallas: Spring Publications, 1970), 93. Besides her identification with robins, Dickinson also claimed, "I live in the Sea always" (L 306).

\section{Works Cited}

Anderson, Charles R. Emily Dickinson's Poetry: Stairway of Surprise. New York: Holt, Rinehart, and Winston, 1960.

Bingham, Millicent Todd. Ancestors' Brocades: The Literary Debut of Emily Dickinson. New York: Harper, 1945.

Cameron, Sharon. Lyric Time: Dickinson and the Limits of Genre. Baltimore: Johns Hopkins UP, 1979.

Cody, John. After Great Pain: The Inner Life of Emily Dickinson. Cambridge, MA: Belknap P of Harvard UP, 1971.

Dickinson, Emily. The Poems of Emily Dickinson. Ed. Thomas H. Johnson. 3 vols. Cambridge, MA: Belknap P of Harvard UP, 1955.

. The Letters of Emily Dickinson. Eds. Thomas Johnson and Theodora Ward. 3 vols. Cambridge: Belknap P of the Harvard UP, 1958.

Emerson, Ralph Waldo. "The American Scholar." Selections from Ralph Waldo Emerson: An Organic Anthology. Ed. Stephen E. Whicher. Boston: Houghton Mifflin Co., 1960. 53-71.

Franklin, R. W. The Editing of Emily Dickinson: A Reconsideration. Madison: U Wisconsin P, 1967.

- The Manuscript Books of Emily Dickinson. Cambridge, MA: Belknap P of Harvard UP, 1981.

Helms, Alan. "The Sense of Punctuation." The Yale Review 69.2 (1980): 177-196.

Honan, Park. "Eighteenth and Nineteenth Century English Punctuation Theory." English Studies 46.2 (1960): 92-102.

Klein, William Livingston. Why We Punctuate; or Reason versus Rule in the Use of Marks. Minneapolis: Lancet, 1916.

Lindberg-Seyersted, Brita. The Voice of the Poet: Aspects of Style in the Poetry of Emily Dickinson. Acta Universitas Upsaliensis, Studia Anglistica Upsaliensia 6. Upsala: Almqvist \& Wiksells Boktryckeri, 1968.

Meyer, Charles F. A Linguistic Study of American Punctuation. New York: Peter Lang, 1987.

Miller, Cristanne. Emily Dickinson: A Poet's Grammar. Cambridge, MA: Harvard UP, 1987.

Morris, Timothy. "The Development of Dickinson's Style." American Literature 60.1 (1988): 26-41.

Simpson, J. A., and E.S.C. Weiner, eds. Oxford English Dictionary. 2nd ed. 20 vols. Oxford: Clarendon P, 1989.

Turner, Joseph A. A Handbook of Punctuation. Philadelphia: J. B. Lippincott \& Co., 1876.

Von Franz, Maric Louise. Interpretation of Fairy Tales. Dallas: Spring Publications, 1970.

Ward, Theodora. "Poetry and Punctuation." Letters to the Editor. Saturday Review (1 963) 46: 25. 